\title{
Essential management competencies of nurses: actions and interactions in the context of the Family Health Strategy
}

\author{
Competências gerenciais essenciais de enfermeiros: ações e interações no contexto da Estratégia Saúde da Família
}

Competencias gerenciales esenciales de enfermeros: acciones e interacciones en el contexto de la estrategia Salud de la Familia

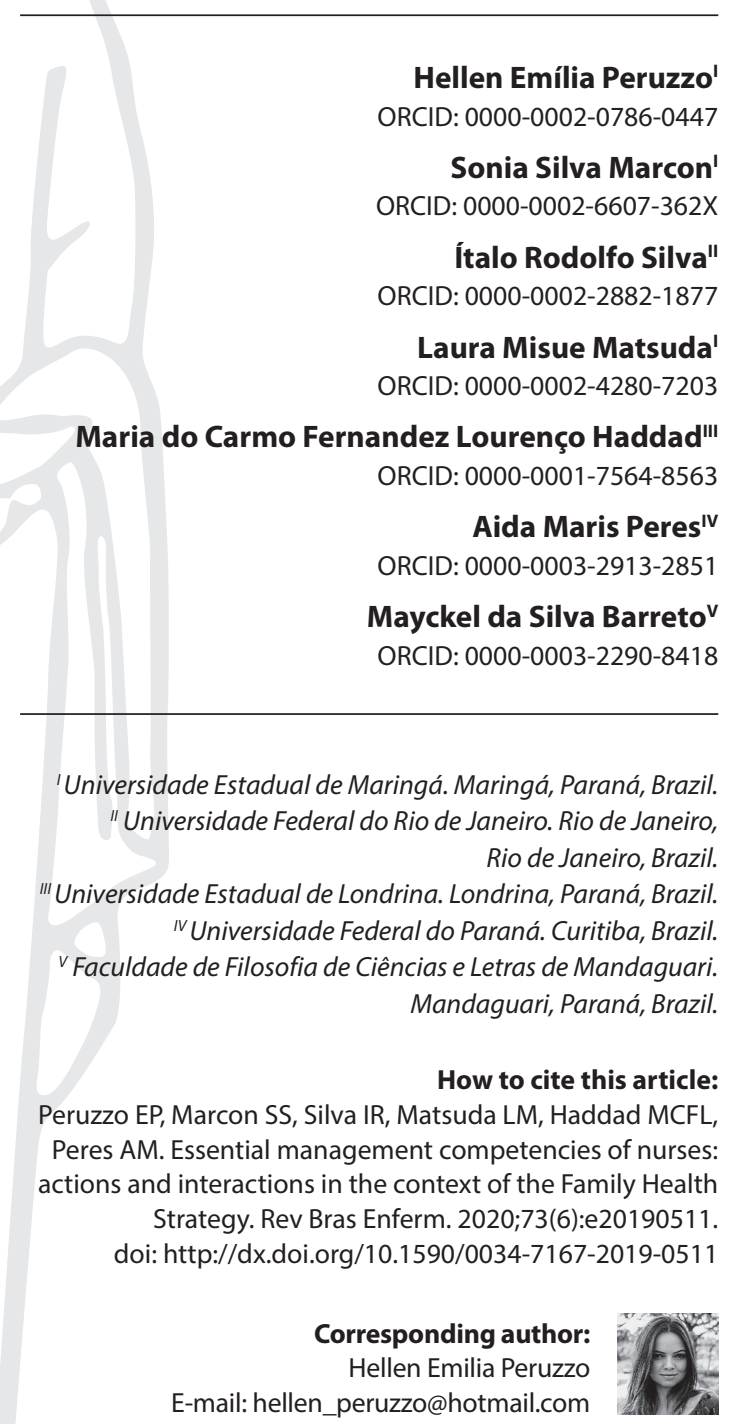

EDITOR IN CHIEF: Antonio José De Almeida Filho ASSOCIATE EDITOR: Andrea Bernardes

Submission: 07-06-2019

Approval: 03-07-2020

\section{ABSTRACT}

Objective: to understand the meanings attributed by the Family Health Strategy (FHS) nurses to the management competencies essential to the performance of their actions. Method: explanatory, qualitative study, whose methodological framework was based on Grounded Theory. A total of 12 Family Health Strategy nurses from a municipality in southern Brazil participated through semi-structured interviews, between December 2018 and February 2019. Results: the experience was understood by the phenomenon "Lapidating management competencies daily to play the role of a nurse in the context of the Family Health Strategy". As action/interaction strategies, the following categories emerged: "Evidencing the management skills of Family Health Strategy nurses" and "Recognizing the need for strategies to work on specificities in the context of the Family Health Strategy". Final considerations: according to the meanings attributed by nurses, there are several essential management skills for the work in the Family Health Strategy, but they are still little worked and developed in this context, mainly because it is a complex health care scenario.

Descriptors: Nursing; Professional Competence; Family Health Strategy; Nursing Administration Research; Practice Management.

\section{RESUMO}

Objetivo: compreender os significados atribuídos por enfermeiros da Estratégia Saúde da Família (ESF) às competências gerenciais essenciais ao desenvolvimento de suas ações. Método: estudo explicativo, qualitativo, cujo referencial metodológico baseou-se na Teoria Fundamentada nos Dados. Participaram 12 enfermeiros da Estratégia Saúde da Família de um município no Sul do Brasil, entre dezembro de 2018 e fevereiro de 2019, por meio de entrevistas semiestruturadas. Resultados: a experiência foi compreendida pelo fenômeno "Lapidando cotidianamente as competências gerenciais para desempenhar o papel de enfermeiro no contexto da Estratégia Saúde da Família". Apresentando-se como estratégias ação/interação, emergiram as categorias: "Evidenciando as competências gerenciais dos enfermeiros da Estratégia Saúde da Família" $\mathrm{e}$ "Reconhecendo as necessidades de estratégias para trabalhar as especificidades no contexto da Estratégia Saúde da Família". Considerações finais: de acordo com os significados atribuídos pelos enfermeiros, são várias as competências gerenciais essenciais ao trabalho na Estratégia Saúde da Família, mas elas ainda são pouco trabalhadas e desenvolvidas neste contexto, sobretudo por constituir um cenário complexo de atenção à saúde.

Descritores: Enfermagem. Competência Profissional; Estratégia Saúde da Família; Pesquisa em Administração de Enfermagem; Gerenciamento da Prática Profissional.

\section{RESUMEN}

Objetivo: Comprender los significados atribuidos por enfermeros de la Estrategia Salud de la Familia (ESF) a las competencias gerenciales esenciales al desarrollo de sus acciones. Método: Estudio explicativo, cualitativo, cuyo referencial metodológico ha basado en la Teoría Fundamentada en los Datos. Participaron 12 enfermeros de la Estrategia Salud de la Familia de un municipio en el Sur de Brasil, entre diciembre de 2018 y febrero de 2019, por medio de entrevistas semiestructuradas. Resultados: La experiencia ha sido comprendida por el fenómeno "Lapidando cotidianamente las competencias gerenciales para desempeñar el papel de enfermero en el contexto de la Estrategia Salud de la Familia". Presentándose como estrategias acción/interacción, han emergido las categorías: "Evidenciando las competencias gerenciales de los enfermeros de la Estrategia Salud de la Familia" y "Reconociendo las necesidades de estrategias para trabajar las especificidades en el contexto de la Estrategia Salud de la Familia". Consideraciones finales: Conforme los significados atribuidos por los enfermeros, son varias las competencias gerenciales esenciales al trabajo en la Estrategia Salud de la Familia, pero ellas son poco trabajadas y desarrolladas en esto contexto aún, principalmente por constituir un escenario complejo de atención a la salud.

Descriptores: Enfermería. Competencia Profesional; Estrategia de Salud Familiar; Investigación em Administración de Enfermería; Gestión de La Práctica Profesional. 


\section{INTRODUCTION}

The concept of competence is broad, as it includes the set of knowledge, skills, and attitudes that allow the individual, inserted in a context, to efficiently perform the tasks that are their own or assigned to them. In this sense, knowing how to act adequately implies integration, mobilization, and transfer of resources that can add knowledge and economic values to the organization, in addition to social value to the individual(1).

When considering the contextual relationship for competencies, for the purpose of this study, health institutions stand out, because the actions developed by professionals in these spaces of action and interaction corroborate the perspective of unreal assets, as they are related to the health-disease process and with people's quality of life. In this context, dealing with skills means prioritizing the development of workers with a view to valuing the right of people to be cared for in the best possible way, respecting ethical, moral, legal, technical and scientific principles.

Among the skills related to the development of the nurse's work, there are the essential management skills that contribute, directly and indirectly, to the improvement of the assistance offered to the population ${ }^{(2)}$.

In Brazil, the National Curriculum Guidelines (DCNs) instituted the following competencies for health courses: Health Care; Decision making; Communication; Leadership; Administration and Management; and Permanent Education ${ }^{(3)}$. In the same sense, the Regional Nursing Council of the State of São Paulo (COREN-SP) also listed a set of essential skills for nurses ${ }^{(4)}$.

In addition to this set of skills, the corporate process is dynamic, and the current work system points to the need for professional self-knowledge so that the worker can recognize and intensify their potential but also identify and minimize their weaknesses ${ }^{(5)}$. To this end, educational processes are essential to creating spaces for reflection and actions that encourage personal development by enabling discussions on significant issues of social and professional performance ${ }^{(6)}$.

Even though the program curriculum of the training institutions in the health area seeks to meet the specifications of the DCN, the competencies established as necessary for training are not fully covered. It is also noteworthy the lack of specific subjects that allow greater depth of each competence, especially on leadership ${ }^{(7)}$.

Thus, with the deconstruction of dominant paradigms in current work systems, it is necessary to consider the need for human capital that develops competencies in a multifaceted and integrated perspective to the team and the organization in which the worker is inserted. In this context, the nurse must go beyond the act of caring, assuming the duties of managing relationships and not only supervising the execution of procedures ${ }^{(8)}$.

With regard to health services, the role of nurses in Primary Health Care (PHC) is an intense provision of care, since the Family Health Strategy (FHS) develops actions that involve promotion, prevention, protection, nursing diagnosis, treatment, rehabilitation, palliative care, harm reduction, and health surveillance, through multi-professional teams ${ }^{(9)}$. It is important, therefore, to emphasize the consolidation of nurses' management skills, as they may influence the quality of care for users and their families.

Furthermore, the analysis of scientific literature on essential management competencies of nurses, both in PHC and in the context of the FHS or in the other scenarios of this professional's performance in the Brazilian context, points out that this is still limited, with important aspects still to be investigated. This is because the sparse studies show that research has focused more on care management, focusing on assistance analysis of the work process and/or the client $^{(10-12)}$. Therefore, there is a gap that needs to be filled with regard to the understanding of how FHS nurses mean essential management skills, since for a reality to be changed, it is necessary, first, to understand the systems of meanings that influence its development.

Therefore, it is worth noting that the FHS and the nursing staff working in this scenario, make an essential contribution to its consolidation in the Brazilian health system. Therefore, it is pertinent to understand in depth the meanings that nurses working in the FHS give to essential management competencies and, from there, develop strategies for their improvement. Based on the above, this study is guided by the question: What is the sense/meaning of essential management skills for the work of FHS nurses?

\section{OBJECTIVE}

To understand the meanings given by nurses of the FHS to essential management competencies in the performance of their actions.

\section{METHODS}

\section{Ethical aspects}

This research was developed in accordance with Resolution $n$. $446 / 12$ of the National Health Council and approved by the Standing Committee for Ethics in Research Involving Human Beings of the signatory institution. It should be noted that all participants signed the Informed Consent Form, in two copies, and were told about the study objectives. In order to preserve their anonymity, they were identified with the prefix "Nur" followed by the ordinal number of the interview (ex: Nur-6).

\section{Theoretical and methodological framework}

The essential managerial concepts and skills proposed by COREN$\mathrm{SP}^{(4)}$ were used as the conceptual basis of the study, directing the collection and data analysis. COREN-SP, in 2007, aiming to develop a booklet for the training of nurses in the state regarding management skills, surveyed with all the technically responsible nurses registered in the organization, and obtained a response from almost 1000 professionals, covering all professional areas. A preliminary document was prepared by the working group and submitted to public consultation, and the suggestions made were also considered ${ }^{(4)}$.

The final document proposed 11 competencies for the full exercise of the nurse's professional activities and, for each of them, guiding actions and indicators are presented that indicate or not their existence. The proposed competencies are: Leadership, Communication, Decision Making, Negotiation, Teamwork, Flexibility, Interpersonal Relationship, Entrepreneurship, Creativity, Systemic Vision, Planning and Organization ${ }^{(4)}$.

As a methodological framework, the principles of Grounded Theory (GT) were applied ${ }^{(13)}$. GT is based on an understanding of the phenomena that emerge from interactions between people, which creates a substantive theory, constituted by a set of categories that 
are interrelated via systematized interactions and relationships. Its main purpose is to understand the interactions and experiences of people inserted in a given social context, in order to highlight strategies developed in the face of the situations experienced ${ }^{(13)}$.

\section{Study design}

Explanatory study ${ }^{(13)}$, with a qualitative approach. It is a method developed from a set of analytical resources that, systematically, enable the construction of a theoretical model that explains the research phenomenon ${ }^{(13)}$.

\section{Methodological procedures}

The study included 12 nurses working in six of the 34 Basic Health Units (BHU) in a large city in Paraná - Brazil. Such units were selected by proximity criteria, as they are located in the same geographical region of the municipality, which is characterized by the large population contingent. For participants selection, the principle of theoretical sampling was respected, as proposed by the GT, which consists of enhancing comparative opportunities of facts to determine how a category varies in terms of its properties and dimensions ${ }^{(13)}$. The inclusion criterion was adopted: being a nurse in the FHS for at least one year. Professionals on leave for any reason during data collection were excluded.

Data collection took place using individual and semi-structured interviews, conducted by a single researcher with experience in qualitative research, between December 2018 and February 2019. They were previously scheduled, had an average duration of 30 minutes, and took place in a reserved space at the BHU itself. In addition to questions about participants' characterization, the interviews were guided by the following initial question: "What meanings do you give to management competencies, those essential to the performance of your work?" Support questions were used for better understanding, and the deepening of the reports was identified from a pre-established script.

The concomitant analysis of the data revealed the need to include new participants in the sample group, however, without the need for training other groups. Data collection was completed when reaching theoretical saturation, that is, the sample composition was finished when the categories presented explanatory significance capable of contemplating the research object ${ }^{(13,14)}$. All interviews were recorded and later rewritten in full.

\section{Data analysis}

Data analysis took place simultaneously with the data collection, by two independent researchers, in a comparative and continuous manner. It took place by coding, based on the three interdependent steps proposed in the GT, open, axial and selective coding ${ }^{(13)}$. In open coding, the concepts were identified by comparing their properties and dimensions. Still in this stage, those under preliminary construction emerged through the titles attributed to each incident, idea or event, seeking to remain reliable to the interviewees' statements. Subsequently, the preliminary codes were grouped by similarities, creating conceptual codes. In axial coding, on the other hand, from a greater abstraction of data, it was possible to group conceptual codes to originate categories and subcategories, with a view to a solid explanation of the phenomenon. Thus, the data acquired higher levels of abstraction and conceptualization to explain the phenomenon investigated. Finally, the selective coding consisted of comparing and analyzing the categories and subcategories identified with the primary data, as well as with the current literature on the subject, and its objective was to develop the categories, as well as to integrate and refine the theoretical model, which allowed the identification of the central phenomenon ${ }^{(13-14)}$.

Each of the researchers ordered the categories according to the paradigmatic model ${ }^{(13)}$. Such an arrangement made it possible to achieve an explanatory coherence between the dimensions that support the theoretical model. In this sense, its structure occurs through the components: phenomenon, causal conditions, intervening conditions, context, action/interaction strategies and consequences $^{(13-14)}$. The independent analyzes were compared and discussed by the group of researchers so that inconsistencies and doubts could be debated and agreed.

\section{RESULTS}

The 12 nurses participating in the study were aged between 31 and 53 years old, ten were female, one with a master's degree and the others, specialists. The time working in the FHS varied between one and 25 years. Based on the analysis carried out, it was possible to identify the central phenomenon "Lapidating management competencies daily to play the role of a nurse in the context of the FHS", which influences the meanings attributed by nurses to essential management competencies. In this perspective, action/interaction strategies were elucidated through two interrelated categories.

It was identified that the management competencies essential for the work of nurses in the scope of the FHS are numerous. The meaning attributed to such competencies is related to the perception of the occurrence of a constant process of improvement, as they are initially acquired in university education and later, in the daily work, are being lapidated. What promotes the sharpening of competencies are the experiences in which the nurse is faced with the role of team leader when he/she needs to mediate conflicts, or even when he/she organizes the work process or applies enterprise.

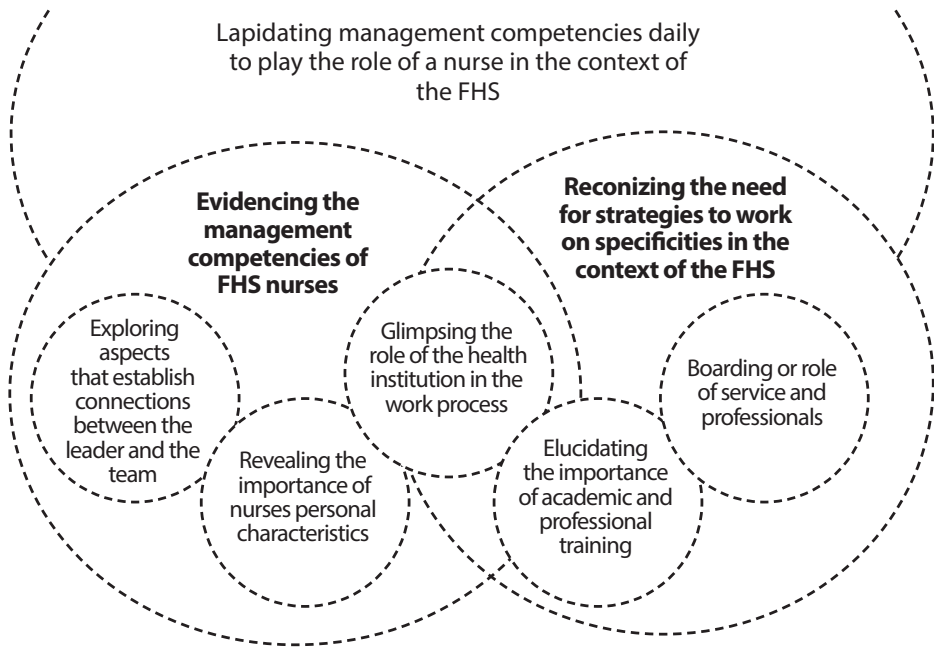

Note: FHS = Family Health Strategy.

Figure 1 - Graphical representation of the component "action/interaction strategies". 
The first category, "Evidencing the management competencies of FHS nurses", consisting of three subcategories, shows aspects related to the competencies attributed by the participants and how much they are codependent. The second, "Recognizing the need for strategies to work on specificities in the context of the FHS", discusses the nurses' desires, as an important ally for the realization of such essential management competencies (Figure 1).

\section{SIGNIFYING THE MANAGEMENT COMPETENCIES OF NURSES IN THE FAMILY HEALTH STRATEGY}

In this first category, it is possible to identify the meanings attributed by nurses to essential management competencies in the management of FHS teams and the skills they find necessary for the continuity of the work process. It is noteworthy that such competencies were presented from connections between the nurse and the other team members, between the nurse's characteristics and that of the health institution.

\section{Exploring aspects that establish connections between the leader and the team}

Based on their experiences as managers of a health team, nurses identify obstacles to becoming leaders, among which they highlight: the challenges of teamwork in the context of the FHS and of being the mediator in the management of conflicts and interpersonal relationships.

Different, but complementary, perspectives on the concept of leadership can be observed and how it should be used by the nurse in the context of the FHS. For example, leadership is perceived both as an intrinsic characteristic of the person and as a skill that can be developed over time and professional experience, through theoretical knowledge and technical capacity (of knowing how to do).

It seems that whoever is a leader is born a leader! Or over time you become! There are people who have more difficulties, I am very shy, but over time you learn! (Nur-1)

Leadership has to be achieved! In nursing you become a leader! But that, by itself, does not mean that all your team will follow what you are saying, because this leadership is imposed, they tell you that you have to lead! The most important thing is to know how to do it! If you don't know how to do it, there's no use demanding! To lead is not only demanding! There must be an initiative! You do a good job and people see and start accepting it! (Nur-2)

Becoming a leader is a challenging process for nurses, once this condition is often imposed on them without feeling properly prepared to exercise this role or even perceiving themselves as the team leader. The experienced mishaps are present in several excerpts of the speeches, overcoming the difficulty of acceptance, of assuming a more directive and/or punitive posture.

\section{I had a hard time accepting the leadership! (Nur-2)}

I have a little hard time with leadership. We often have to punish and I don't like it, I prefer to talk! It is a challenge, because the people llead are older than me! (Nur-6)
We need to demand and because of it we are seen as bad, harsh people! (Nur-3)

Behavior towards the team can be changeable throughout life at work. The more autocratic posture, typical at the beginning of a career, can be shaped over time, when observed that it is not always the best strategy for resolving various situations and conflicts.

My assistant says "wow, but when you started you were a lot more severe, someone who would demand, picky, very harsh! And nowadays, you are easier"! So, these are situations that we go through, that makes us tired! And we also know that being in a team just getting yelled at, demanding every day, is not cool! (Nur-6)

Among the several essential competencies challenging for the management of the FHS is teamwork. Keeping professionals motivated to carry out collaborative work towards the same goals requires collective effort.

The nurse alone does nothing! At FHS you have to work as a team! If everyone has a way of thinking and nobody gives in, there is no consensus! (Nur-1)

I always tell my team that nobody needs to be friends with anyone, but we have to work as a team! We have to keep communication and respect at least! (Nur-3)

And each one has a role. I don't do the doctor's job the and vice versa. (Nur-10)

The nurse must also play the role of mediator in conflict management and interpersonal relationships between team members. This mediation can also sometimes cause suffering for nurses, as they constantly involve themselves in stressful and conflicting situations that last over time without a prospect of resolution.

The interpersonal relationship is a critical point! There are times when we need to sit down argue about issues! And then, as time goes by, you don't mind anymore, because you discuss it and don't solve it, so it's an annoying situation! Sometimes, I realize that the team is asking me for an attitude, but there are times when you say "I don't care, I'm tired"! We have to stay involved to calm things down! You get discouraged, unfortunately (Nur-3)

\section{Revealing the importance of nurses' personal characteristics}

In this subcategory, personal characteristics were identified in the self-management of competencies as professionals, such as: the difficulty in being creative and stimulating innovation in the FHS; communication as an important tool in the management of FHS teams; the capacity for resilience when facing adversity; and the need to plan activities.

Although important in the context of the FHS, creativity and entrepreneurship integrate the skills that present the greatest difficulties, largely due to the characteristics of the PHC and the profile of the care offered, since most demand is for care for people with disabilities, chronic diseases. Thus, in addition to maintaining a constant creative process, they must also encourage the innovative spirit in their teams, which is not always the case because they sometimes meet professionals with poor attitude. 
One of the aspects I miss most is entrepreneurship, in the sense of creating, being creative, doing different things! For example, innovating in groups, doing things differently, I am done with the old way! To motivate both people and patients! (Nur-7)

I don't have much creativity, this is of the person! In terms of addressing the population, asking for this, for that! I ask my CHWs what they think! (Nur-11)

Personally, I also have a little hard time! I am that person who sits and sees what I have to do and I try to think about the situation! And sometimes, it doesn't work and it's hard to get away from it, because we make a plan in our head and we can't go very far with it!! (Nur-3)

Communication is an important tool in the management of FHS teams. In addition to having great relevance within the team, its improvement is essential to the personal context, even if it is hard to face it.

Communication is the first thing! I am not to a very communicative person. If I have to say something, I go to the person and say it! (Nur-3)

You are afraid to speak, you are afraid to expose yourself in public! I hated it, but I had to learn it! I saw that in Family Health you have to talk to the community, you have to talk to people, you have to talk to your team, you can't be afraid to talk! (Nur-1)

It was observed the capacity of the nurse to adapt to the adversities of the work process, that is, flexibility, as it changes in the face of obstacles and seeks alternatives to reinvent him/herself and continue the assistance. However, despite the potential for adaptation, they feel passive before it, precisely because they have this characteristic.

Nurses are "chameleons" in fact. They live what the environment requires from us! Today a doctor was saying that if she arrives tomorrow and there is no fan in her room, she will leave. And we work without a fan in this heat! They complain that they need to install air conditioning there, and for her [doctor], by tomorrow there will be a fan (Nur-10)

The need for planning and organization was also evidenced in the work context of FHS nurses. Despite the understanding of its meaning in the range of FHS activities, the difficulty of planning still persists, as they feel consumed by the demand for work or because they do not adopt the proposal as behavior.

We are not very used to planning even in everyday life! We keep things going! I believe that planning is to anticipate what will happen! When you anticipate, it means that at least it crossed your mind! If you didn't even imagine that it could happen, you get scared! So planning is crucial! (Nur-2)

\section{Glimpsing the role of the health institution in the work process}

In this third subcategory, it is possible to identify the institution's responsibility with the development of nurses' management competencies and the limitations involved in this interaction. Thus, difficult aspects that permeate the negotiation were elucidated, especially when the bargaining power is reduced when realizing that the nurse does not have what to offer to employees/team members.

Negotiations are not just up to me! So, I feel a certain difficulty! There is often nothing to give in return! (Nur-6)

To negotiate with CHW, because sometimes they say no, I can't! What can I demand from the four CHWs if there should be 10 of them? What else can l ask them for? (Nur-11)

Nurses also refer to the lack of autonomy in decision making in the health service. Decision making can be influenced by administrative issues of top management, which limits them as managers of their teams, both in the management of processes and human resources. In this sense, autonomy has a fundamental role in maintaining this competence.

Autonomy is a little blocked! What we would like to implement is not always achieved because we have to follow pre-established rules by the municipal management! (Nur-8)

The FHS nurse needs time and autonomy, and we don't have that! We work and have to make it clear to people that I can only advance to some point! (Nur-6)

We need a little more autonomy. Protocols give you limited freedom! Autonomy to make a decision, especially in relation to the $\mathrm{CHW}$, to be able to say that such a person does not perform his/ her work well, that he/she needs to be excluded because he is disturbing the team! (Nur-11)

\section{RECOGNIZING THE NEED FOR STRATEGIES TO WORK SPECI- FICITIES IN THE FHS CONTEXT}

The second category recognizes the need to implement coping strategies to improve management competencies, such as: the need to establish a correlation between theory and practice; permanent education not limited to technical issues only; team meetings; and innovative intervention proposals.

\section{Elucidating the importance of academic and professional training}

It is emphasized the importance of academic training with a closer relationship between theory and practice, so that management competencies can begin to be developed within universities. Although this approach is important, part of this development is carried out throughout professional practice, as they gain experience

At academic training there was no clear connection between theory and practice! In theory, we even had it, but in hospital practice there wasn 't any! So, the administration and leadership in the internship we would be about organizing the unit, the nursing station, the reports! (Nur-2)

Idon't think that the content worked at the college was insufficient, but I think that, over the years, I saw that it is difficult to put into practice! (Nur-3) 
The results corroborate the understanding that, after academic training, the promotion of spaces for improving skills as managers should be a commitment of health institutions. In this sense, permanent education should not be limited to technical issues only.

You also need ongoing training on the job, not only on the technical side, but also on management! It could be carried out by the Health Department, in partnership with universities! Idon't remember having anything like that, because it's always the technical part! Working with protocol is that, it doesn't change, now working with the team and the patient involves other issues! We have to know how to deal with them! (Nur-7)

Precisamos de educação permanente! Ela vem, mas não da forma que a gente gostaria We need permanent education! It comes, but not in the way we would like!! (Nur-6)

\section{Addressing the role of service and professionals}

This subcategory reinforces the importance of team meetings as coping strategies, since they contemplate planning and allow listening and encouraging innovation. It is emphasized that this is a proposal that must be accepted by all team members, by the health institution and conducted by the nurse.

In public health, in primary care, this issue is easier to deal with! For example, every team has meetings where planning is done! There is the moment to talk! The CHW is having difficulty in such a point, the doctor in such an issue! (Nur-2)

Finally, there is a need for innovative interventions in this context, which go beyond the traditional proposals already known by nurses, in order to enable an environment of reflection, self-knowledge and self-assessment, in addition to providing the opportunity to improve skills for the management of their teams and more qualified assistance.

It needs to be a dynamic thing, that will make some difference to the service! Because when you try some things and "ah ... I've seen that ...", you think "it won't change", because who has been there for a long time already knows where the problem is installed! I believe that what we can change the most is ourselves, because trying to change the other is useless, it is difficult. (Nur-10)

Either I'll take the time to do this or I'll keep putting out the fire until I don't know when! It may not change my decision-making, because sometimes I will run into administrative issues that are outside our reach, but I can do it differently! (Nur-11)

In this perspective, it is believed that the presence of other professionals, even external to the team, can contribute to the reflection and development of management competencies, precisely because they have a different view of the actors involved. This can contribute to the work process, as it supports nurses through a different perspective on work and their relationships.

We never stop and reflect on it! The fact that we stop, when see someone from outside, I have no doubt! (Nur-2)

I think it is always welcome to discuss these matters with outsiders! It's like planting seeds planted that sometime will bloom! Because, sometimes, we end up settling down! (Nur-3)

\section{DISCUSSION}

From the perspective of the surveyed nurses, essential management competencies can have different meanings depending on the work process that the worker develops in the FHS. Among the competencies listed by COREN-SP, that of "systemic vision", which concerns the ability to understand the institution as a whole and the relationship between the parts that comprise it ${ }^{(4)}$, showed less visibility in the results of this study compared to others. Such a result may be related to the idea of the old fragmented assistance and the non-integrality of health actions in all contexts, challenges that permeate the different professional categories and which must be overcome in the deconstruction of care management paradigms ${ }^{(15)}$.

Leadership was the most prominent competence, precisely because it permeates the others and is in all contexts where nurses work. However, it was identified that being accepted and leading the team is still a challenge experienced in the exercise of these skills. For the nurse to be able to exercise leadership, he/she must establish interpersonal relationships in order to inspire people regarding the goals and objectives to be achieved by the team and not only implement decisions ${ }^{(5)}$. Thus, the individual cannot lead if he/she is not able to overcome his/her own potential, as it is necessary to influence people. This perspective of influence works by energizing the team or the vision of the future and, consequently, motivating them by identification and not by rewards and punishments ${ }^{(5)}$.

In a study carried out with primary care nurses who also used GT, leadership presented itself as an intrinsic characteristic or capable of being developed, especially during academic training ${ }^{(16)}$, corroborating the results of this study. This aspect reinforces the importance of training institutions in the process of building the professional identity of nurses, providing opportunities for the development of leadership and other management competencies. It is, therefore, necessary to create strategies that enable the development of essential skills in all fields of nurses' activities, including in the context of the FHS. It is then necessary to create strategies and changes in academic education that enable the student to connect the relationship between theory and practice, as well as the development of essential skills in all fields of nurses' activities, including in the context of the FHS. In this sense, supervised curriculum internships, for example, can be an essential tool for this process ${ }^{(17-18)}$.

However, innovative teaching proposals, by themselves, do not validate students' competencies. There must also be a commitment by teachers and educational institutions in order to collaborate with pedagogical advances and flexible curricula. Despite recognized advances in discussions regarding the need for change, the difficulties in deconstructing conservative teaching models persist. The teacher's attachment to the contents in the curricula models, aimed at the execution of procedures little discussed in the principles of practice based on scientific evidence, still prevails in Brazil ${ }^{(19)}$. These aspects may influence the development of the competencies of the future nurse, mainly due to the difficulty of establishing parallels between theoretical content and professional practice ${ }^{(20)}$.

Furthermore, it is necessary to consider the development of competencies in an expanded perspective. With this approach, the teaching-learning process will enable the use of more appropriate tools. Likewise, in the practical context, it is the systems of professional interactions that will allow conditions for the improvement 
of the skills necessary for the social demands required of nurses in the exercise of their profession ${ }^{(16)}$.

It is highlighted that the learning process for nursing management will only reach its changing potential upon innovative technical-pedagogical practices and changes in training strategies, to value the emancipatory educational practice, encouraging daily reflection, questioning, and social transformation ${ }^{(21)}$, besides competencies training ${ }^{(22)}$.

Despite the above considerations, overcoming challenges related to teaching and learning has not been an easy task. Some initiatives are already being developed in order to minimize conservative and traditional education. As examples, we can mention the active and problematizing methodologies ${ }^{(21)}$, the use of practice scenarios that stimulate the student's creativity, university extension projects, and curricula models that enable professional training in a self-managed manner by the students themselves ${ }^{(19)}$.

Another aspect mentioned by the participants is the appreciation of teamwork, mainly because it involves a multidisciplinary and interdisciplinary team. In this sense, those who work in the FHS face numerous challenges to keep effective teamwork, especially concerning interpersonal relationships, as they are always in conflict situations, which can contribute to the distance between their members. Being put to the test, because of different points of view, culture, beliefs, and personalities, in the same corporate environment is not an easy task ${ }^{(23)}$. It is up to the nurse to develop the ability to encourage teamwork so that it is constant and integrated.

These challenges can be overcome with the implementation of strategies such as team meetings, recognition, and appreciation of member's role and strengthening of the bond between team members, which also contributes to better performance and planning of activities. Also, aspects such as active listening, communication, empathy, and respect for the particularities of each profession are essential for the harmony and implementation of more collaborative practice ${ }^{(24-25)}$.

When discussing teamwork, it is inherent to associate it with interpersonal relationships, since the quality of these relationships/ integrations has an impact on the work process. The results of this research corroborate those of similar studies carried out in the states of Paraná ${ }^{(25)}$ and Rio de Janeiro ${ }^{(26)}$, which show weaknesses among primary care managers regarding conflict management in their daily work, as it involves relationships interpersonal, leadership, negotiation and decision making ${ }^{(25)}$.

Some difficulties related to interpersonal relationships, pointed by the nurses working in the FHS, is regarding public services, that sometimes do not have protocols for punitive measures, have professionals without ability nor training to work in this care context and do not have a permanent employee evaluation program ${ }^{(27)}$. All of these factors, alone or together, hinder interpersonal relationships ${ }^{(27)}$, with a consequent impact on the care provided.

The difficulties related to interpersonal relationships highlight the importance of professional development and preparation to understand, support and interact with the conflicts of the work team. In this context, the nurse, as a manager, should recognize him/herself as a member of the team, but as the main mediator of conflicting situations, which reinforces the importance of permanent education, especially for improving management competencies ${ }^{(25)}$.

The study participants frequently mentioned the difficulty in keeping creative and innovative in the FHS. Still, in the context of personal characteristics, they also referred to difficulties related to effective communication, planning/organization, and flexibility/ resilience within services. In this sense, all the skills listed are essential for this scenario. It is essential to highlight that as institutions invest in conditions to innovate, they simultaneously promote job satisfaction, and this has an impact on the quality of care ${ }^{(28)}$.

A similar study that analyzed the nurses' competencies for management in $\mathrm{BHU}$ identified that, often, they need to readapt themselves, give new meanings, and new uses to work tools. In other words, they need to reinvent care and reconfigure care management with what is available. For this reason, resilience/ flexibility is an essential competence for the manager, as well as being creative and having the ability to adapt ${ }^{(27)}$.

Communication is also understood as an important tool in the management of FHS teams, both in the context of interprofessional, professional-patient, and professional-family relationships. Despite being considered a characteristic of the human being, as part of the knowledge acquired since birth and in constant improvement, it represents a challenge for health professionals and institutions. However, really instituting and developing it requires effort, since each experiences it in a unique way ${ }^{(29)}$.

Some nurses showed in their reports an absence of proactivity in the development of management competencies when they demonstrated that they expected the institution to guarantee autonomy. Concomitant to this, they have difficulties in organizing themselves in order to achieve spaces of autonomy that lead to decision making and negotiation with the team, competencies that make up their professional role. On the other hand, health institutions also play an essential role in the development of such competencies. A study found that the main obstacles pointed by nurses to acquire or improve their skills are: lack of time, shortage of human resources, and overload of activities and work, and lack of autonomy. To diminish it, some initiatives can be adopted, such as training, with a view to qualifying these managers in the face of the numerous challenges of $\mathrm{PHC}$ and $\mathrm{FHS}^{(26)}$.

Thus, sometimes FHS nurses feel they do not have the autonomy to negotiate and decide task priorities, as well as to decide on the necessary resources for their professional improvement. Such a situation could be seen in this study, due to the absence of reports on the use of management tools that would support them in time management, action planning, and information analysis, in order to support decision making and the establishment of priorities. Besides, there are reports of being under constant pressure and facing many demands, which can also trigger the overload of activities and accumulation of tasks. Such aspects weakens autonomy and can result in a shortage of time allocated to the evaluation of work or learning opportunities.

It is noteworthy that although the professionals realize the need for training for management in nursing and are willing to this, institutional factors limit the growth and performance as managers as interpersonal development of nurses is not a priority for the institution ${ }^{(26)}$. 
The dimension and complexity of the assistance offered by $\mathrm{PHC}$ is another challenging aspect, mainly because it involves a range of activities, which go beyond those initially proposed by the programs addressed to the FHS. Thus, it is also the nurse's role to mediate the work and decision-making process. These activities, however, contribute to work overload and the abdication of essential issues, such as the development of management competencies ${ }^{(27)}$.

In this perspective, health services can act more effectively through permanent education, not limited to technical training, but paying attention to other aspects of the work process. When institutions provide additional training for the development of management competencies, the chances of being more productive, effective and efficient in offering quality care increase ${ }^{(30)}$.

In this sense, permanent education is shown as a strategy capable of transforming the manager's working conditions and solving obstacles that hinder the reach of his governance. The false autonomy offered to nurses, verticality in the care planning process, and the lack of participatory management are barriers to the development of their skills. In this sense, the lack of proposals for permanent education is a gap that affects the entire work process ${ }^{(28)}$.

It is also worth mentioning that professionals are already exhausted from traditional educational approaches, perceived as boring and not very resolving. They need innovative intervention proposals that arouse interest in the development of skills and behavioral changes, created based on contributions from the professionals who act daily in the work scenario. Thus, management competencies must be developed through the articulation of organized skills, practices, and knowledge, built by academic training and permanently in professional nursing practice ${ }^{(31)}$.

\section{Study limitations}

Although the data analysis process, developed according to comparative coding - as proposed by the GT - has been carried out satisfactorily, we highlight the fact that data collection took place at the BHU itself, during nurses' working hours and in a single occasion. This situation may have been a limiting factor in the time addressed to the interviews and, consequently, to the data obtained. This is because the reflective depth can be affected when the participant is concerned with issues outside the interview, for example.

\section{Contributions to the area}

Based on the results evidenced by the understanding of the meanings attributed by nurses of the FHS to management competencies, activities that enhance these competencies in the academic and work environment can be implemented. In this sense, implementing permanent education strategies in health institutions can contribute to the improvement of management competencies. Also, it is necessary to strengthen these contents in future nurse's training to provide a learning environment that addresses these aspects.

\section{FINAL CONSIDERATIONS}

According to the meanings attributed by the study nurses, the management competencies required for the full development of the nurses' work process in the FHS are numerous and are presented in a multifaceted perspective. In this way, they attribute a dynamic and procedural relationship to the skills that they mean in this context of interactions, that is, each professional considers the set of skills in an interdependence relationship and at different times and perspectives.

However, they see in their meanings that, although there are many skills necessary for the development of the work process, in the context of screen interaction, strategies are needed that better prepare nurses to develop and implement them in their daily life. Thus, they show proposals such as curriculum changes that meet the real demands of health and future professionals, in order to provide nurses with the tools to manage their teams in the world of work.

Also, the study points to the importance of more significant nurses' proactivity and greater commitment from institutions in terms of seeking and offering space for the development of management competencies of FHS nurses, which will enable their improvement and, consequently, it will provide a more conclusive work environment with good collaborative practices.

\section{REFERENCES}

1. Fleury ACC, Fleury MTL. Estratégias empresariais e formação de competências. São Paulo: Atlas; 2007.

2. Isfahani HM, Aryankhesal A, Haghani H. The Relationship Between the Managerial Skills and Results of "Performance Evaluation "Tool Among Nursing Managers in Teaching Hospitals of Iran University of Medical Science. Glob J Health Sci. 2015;7(2):38-43.doi: $10.5539 / 1916-9736$

3. Ministério da Educação (BR). Resolução CNE/CES n 3/2001: sobre as Diretrizes Curriculares Nacionais do Curso de Graduação em Enfermagem. Diário Oficial da União, Brasília, 9 nov, 2001. Seção 1. p. 37.

4. Conselho Regional de Enfermagem de São Paulo (COREN-SP). Projeto Competências [Internet]. São Paulo; 2009 [cited 2019 Mar 8]. Available from: https://pt.slideshare.net/betinhameneses/projeto-competencias-enfermagem-gesto

5. Bennis W. A formação do líder. São Paulo: Atlas; 1996.

6. Massaroli M V. Group dynamics in the development of competences of health professionals. J Health NPEPS [Internet]. 2016 [cited 2019 jun 21];1(2):278-86. Available from: https://periodicos.unemat.br/index.php/jhnpeps/article/view/1581/1507

7. Madureira GC, Santos MF, Santos DSS, Batalha EMSS. Reflexão sobre a enfermagem e o gerenciamento das unidades básicas de saúde. Rev Baiana Saúde Pública. 2017;40(4):848-61. doi: 10.22278/2318-2660 
8. Carmelo SHH, Rocha FLR, Chaves LDP, Silva, VLS, Soares MI. Competências profissionais e estratégias organizacionais de gerentes de enfermagem. Ciencia y Enfermaria, XXII )1): 75-86,2016.

9. Ministério da Saúde (BR). Secretaria de Atenção à Saúde. Departamento de Atenção Básica. Política Nacional de Atenção Básica. Brasília; 2017.

10. Arantes LJ, Shimizu HE, Merchán-Hamann E. The benefits and challenges of the Family Health Strategy in Brazilian Primary Health care: a literature review. Ciên Saúde Coletiva. 2016;21(5):1499-509. doi:10.1590/1413-81232015215.19602015

11. Argenton IS, Pilecco RL, Dolinski C, Medeiros CRG. A Análise de Trajetórias Assistenciais como Metodologia de Integração Ensino-Serviço na Saúde. Rev Bras Educ Med. 2018;42(4). doi: 10.1590/1981-5271

12. Facchini LA, Tomasi E, Dilélio AS. Quality of Primary Health Care in Brazil: advances, challenges and perspectives. Saúde Debate. 2018;42(1):208-222. doi: 10.1590/0103-1104

13. Strauss AL, Corbin J. Pesquisa qualitativa: técnicas e procedimentos para o desenvolvimento de teoria fundamentada. 2a ed. Porto Alegre (RS): Artmed; 2008. 288p.

14. Silva ÍR, Leite JL, Trevizan MA, Mendes IAC, Silva TP, Lins SMSB. Learning through research: from teaching science to the sphere of nursing care. Esc Anna Nery. 2017;21(4). doi:10.1590/2177-9465

15. Magnago C, Pierantoni CR, Carvalho CL, Girardi, SN. Nurse training in health in different regions in Brazil. Rev Bras Saúde Matern Infant. 2017;17(1): S219-S228. doi: 10.1590/1806-9304201700s100010

16. Lanzoni GMM, Meirelles BHS, Cummings G. Práticas de liderança do enfermeiro na atenção básica à saúde: uma teoria fundamentada nos dados. Texto Contexto Enferm [Internet]. 2016 [cited 2019 Jan 08];25(4):2-9. Available from: http://www.scielo.br/pdf/tce/v25n4/pt_01040707-tce-25-04-4190015.pdf

17. Ramos TK, Nietsche EA, Cogo SB, Cassenote LG, Böck A, Martins FS. Estágio curricular supervisionado e a formação do enfermeiro: atividades desenvolvidas. Rev Enferm UFSM. 2018;8(1):59-71. doi: 10.5902/2179769228124

18. Alves MP, Cunha KS, Higashi GDC, Santos JLG, Erdmann AL. Unveilingactions and interactions of nursing professors in teaching management. Cienc Cuid Saude. 2019;18(3)e45139. doi: 10.4025/cienccuidsaude.v18i3.45139

19. Vieira MA, Souto LES, Souza SM, Lima CA, Ohara CVS, Domenico EBL. Diretrizes Curriculares Nacionais para a área da enfermagem: o papel das competências na formação do enfermeiro. Rev Norte Min Enferm [Internet]. 2016[cited 2019 Jun 13];5(1):105-21. Available from: http:// www.renome.unimontes.br/index.php/renome/article/view/102/148.

20. Trombelli FSO, Ferreira AMD, Oliveira JLC, Marcon, SS, Matsuda LM. Competências gerenciais: análise curricular de cursos da área da saúde da rede pública. Rev Saúde Comun [Internet]. 2018 [cited 2020 Feb 5];1(1): 20-26. Available from: http://revista.unespar.edu.br/index.php/ saudeecomunidade/article/view/13/5

21. Caveião C, Zagonel IPS, Coelho ICM, Peres AM, Montezeli JH. Percepção de docentes sobre o processo de aprendizado em administração de enfermagem. Cogitare Enferm [Internet]. 2015 [cited 2019 Apr 10];20(1):103-11. Available from: http://revistas.ufpr.br/cogitare/ article/ view/40628

22. Meira MDD, Kurcgant P. Educação em enfermagem: avaliação da formação por egressos, empregadores e docentes. Rev Bras Enferm [Internet]. 2016 [cited 2019 Apr 11];69(1):16-22. Available from: http://www.scielo.br/pdf/reben/v69n1/0034-7167-reben-69-01-0016.pdf

23. Peruzzo HE, Bega AG, Lopes APAT, Haddad MCFL, Peres AM, Marcon SS. The challenges of teamwork in the family health strategy. Esc Anna Nery. 2018;22(4):e20170372. doi: 10.1590/2177-9465-ean-2017-0372

24. Duarte MLC, Boeck JN. O trabalho em equipe na enfermagem e os limites e possibilidades da estratégia saúde da família. Trab Educ Saúde [Internet]. 2015 [cited 2019 Apr 30];13(3):709-20. Available from: http://www.scielo.br/pdf/tes/v13n3/1981-7746-tes-13-03-0709.pdf

25. Nunes EFPA, Carvalho BG, Nicoletto SCS, Cordoni Junior L. Managerial work in Basic Health Units of small municipalities in Parana, Brazil. Interface (Botucatu). 2016;20(58):573-84. doi: 10.1590/1807-57622015.0065

26. Marinho AS. Management Skills in Primary Care: Evaluation of Social Skills of Managers Nurses in Family Health Teams[Dissertação]. Instituto de Educação. Universidade Federal do Rio de Janeiro. Seropédica, RJ, 2018. 129 pages.

27. Fernandes JC. Educação permanente em saúde: estratégia para o fortalecimento de competências gerenciais dos enfermeiros de unidades básicas de saúde. [Dissertação]. Escola De Enfermagem Aurora De Afonso Costa, Universidade Federal Fluminense, Niterói, RJ, 2017. 123p

28. Porcaro-Sousa GZ, Fukuda CC, Laros, JA. Relação entre condições para criatividade e satisfação no trabalho de pesquisadores. Aval psicol. 2015;14(2):169-178. doi: 10.15689/ap.2015.1402.01

29. Dalcól C, Garanhani ML, Fonseca LF, Carvalho BG. Communication skills and teaching-learning strategies: perception of nursing students. Cogitare Enferm. 2018;23(3):e53743. doi: 10.5380/ce.v23i3.53743

30. Meissner E, Radford K. Importance and performance of managerial skills in the Australian aged care sector - a middle managers' perspective. J Nurs Manag. 2015;23(6)784-793. doi: 10.1111/jonm.12208

31. Sade PMC, Peres AM, Wolff LDG. A formação das competências gerenciais do enfermeiro: revisão integrativa. Rev Enferm UFPE. 2014;8(6):1739-45. doi: 10.5205/reuol.5876-50610-1-SM.0806201438 